\title{
The Opacity of a Multinational Company's Organization, Legal Structure and Power
}

\author{
What Type of Corporate Information Must a Multinational Company Make Public Pursuant to \\ Dutch Law? Options for Improving Dutch Law: Better Access to Corporate Information for \\ Stakeholders
}

Tineke E. Lambooy, Rosalien A. Diepeveen, Kim Nguyen \& Sander van 't Foort*

\section{Introduction}

\subsection{Introduction and Objectives}

In January 2013, the District Court of The Hague reached a decision concerning the responsibility for remedying certain oil spills in Nigeria. ${ }^{1}$ The Dutch NGO Milieudefensie (Friends of the Earth Netherlands) and four Nigerian farmers had initiated these lawsuits against Shell Petroleum Development Company of Nigeria LTD (hereafter: SPDC) and its ultimate parent company, Royal Dutch Shell PLC (hereafter: RDS). They had argued that SPDC should be held responsible for the damages caused by various oil spills in Nigeria. They had also stated that RDS should be held responsible because it could exert control and had decision-making power over the whole Shell group including SPDC's operations and that RDS had not taken adequate measures to prevent the spills.

The basis of the claims was tort for negligence and hence the claimants had to prove their claims. This proved to be very difficult due to the limited public access to corporate information about SPDC's organization of its business operations, policies, manuals and emergency plans regarding spills. Also, the claims against the parent company, RDS, appeared difficult to substantiate with facts due to the lack of concrete publicly available information concerning the business organization and legal structure of the Shell group and

Dr. T.E. Lambooy, LL.M., is an associate professor at Utrecht University's Molengraaff Institute for Private Law and at Nyenrode Business University's Center for Sustainability. She is the author of Corporate Social Responsibility. Legal and Semi-Legal Frameworks Supporting CSR (Kluwer, 2010). P.K. Nguyen obtained her LL.M. degree at Utrecht University Law School. R.A. Diepeveen and S. van 't Foort are currently pursuing an LL.M. degree at Utrecht University Law School. The authors are very grateful to R. Hordijk, LL.M., for supporting them in the research on this topic and to K. Hooft, LL.M., for reviewing the draft contribution.

1. Rechtbank 's-Gravenhage 30 January 2013, LJN BY9850; Rechtbank 'sGravenhage 30 January 2013, LJN BY9845; Rechtbank 's-Gravenhage 30 January 2013, LJN BY9854. the impossibility for the claimants to obtain the relevant factual information via legal action. ${ }^{2}$ Although the court ruled that SPDC could be held responsible for certain damages caused by oil pollution, it did not find RDS accountable. Appeals were filed on 1 May $2013 .^{3}$

The difficulty for the claimants in substantiating their claims had alarmed the Dutch NGOs Amnesty International (Netherlands department) ${ }^{4}$ (hereafter: AI NL) and the Centre for Research on Multinational Corporations $^{5}$ (hereafter: SOMO). In their view, there is a lack of transparency with regard to multinational companies' organizational and legal structures as well as their business activities. They perceived that it is very difficult for victims and other stakeholders to obtain necessary information about these structures. The two NGOs commissioned a research assignment to the first author of this article, who is associated with the University Utrecht (Molengraaff Institute for Private Law), and two of her colleagues (who also contributed an article to this issue of The Dovenschmidt Quarterly about their part of the research assignment).

The AI NL and SOMO assignment had the objective to analyze the current laws applicable to 'Dutch' multinational companies (hereafter: MNC) (see Section 1.3 for a definition) with regard to corporate transparency and hence to identify options for improvements. A nonpublic academic report was produced by the Utrecht researchers and delivered to AI NL and SOMO in July 2012. Additionally, in November 2012, an academic seminar was organized by the first author of this contribution in collaboration with AI NL to discuss the findings of the study. This seminar was part of the Ius Commune Research Institute's annual conference. ${ }^{6}$ Academics from Utrecht University, Maastricht University, the University of Amsterdam and from the University of Leuven participated in the discussion.

Please see the website of Friends of the Earth Netherlands. See also the contribution of L. Enneking in this issue of The Dovenschmidt Quarterly about document disclosure in litigation before a Dutch court.

3. See the website of Friends of the Earth: <http://www.milieudefensie.nl/ english/shell/news/nigerians-and-milieudefensie-appeal-in-shell-case>.

Please see the website of Amnesty International.

Please see the website of SOMO.

Lambooy et al. 2013 (forthcoming). 
A prior study on human rights violations and tort litigation, conducted in 2011 by the same Utrecht team of CSR specialists for AI NL and SOMO, had supported the suggestion that the layered, complex and international legal structure of an MNC, coupled with the opaque organizational division of tasks and lines of instruction, can be a major obstacle to hold MNCs accountable and liable in civil litigation in the Netherlands. ${ }^{7}$ One of the reasons mentioned was that for a victim of a human rights violation, it is difficult to obtain detailed information about e.g. (i) the level of environmental precaution that a particular MNC applies in each country where it operates and (ii) the internal group rules applicable to remedy any environmental pollution or harm that may occur in connection with the business activities. For an outsider, it is also difficult to find out which employees or legal entities within a group are responsible for which tasks, e.g. for the avoidance of corporate corruption, pollution or potential human rights infringements related to the business activities. Consequently, if a conflict emerges between a victim and an MNC, it is almost impossible for the victim to determine who should be blamed for it.

The 2012 Utrecht University research group studied the theme of corporate transparency more in depth. The resulting report displayed what information can be obtained in regard of a Dutch MNC and what information cannot be obtained. The report also contained suggestions on how to amend Dutch laws to address the present gaps in corporate transparency.

The objective of this contribution to The Dovenschmidt Quarterly is to disseminate the findings of the analysis of the 2012 Utrecht study and to prompt international academic discussion about the options for improving pertinent (Dutch) law. In line with the 2012 Utrecht study, the central question of this contribution is:

What type of information must a multinational company make public pursuant to Dutch law and how can Dutch law be improved so that corporate information is better accessible for stakeholders?

Not only are claimants in tort cases interested in this type of corporate information. Various other stakeholders including institutional investors also demand companies to be more transparent and to communicate in a disciplined way about their environmental, social and governance (ESG) performance and policies. ${ }^{8}$ Investors want to obtain corporate information, which is presented in a structured way and covers all material aspects of the business organization, legal structure and corporate activities, and which is fact based and verified by an external auditor. In response to all the attention for the subject of corporate social responsibility (CSR), there is

7. This study was conducted in 2011 and outlines the possibilities and obstacles that are of importance for holding Dutch MNCs liable under Dutch law for human rights and environmental abuses abroad. The results of the study are shared (only in Dutch) in Enneking et al. 2011.

8. See the website of the Principles of Responsible Investment (PRI): $<$ www.unpri.org/>. See also Eccles \& Serafeim 2011. growing awareness among MNCs of the importance of ESG reporting and stakeholder engagement. Many MNCs today consult with their stakeholders when preparing their annual and/or sustainability report. ${ }^{9}$

The need for corporate transparency has also been picked up by the European Parliament (hereafter: EP) and the European Commission (hereafter: Commission). On 12 December 2012, the Commission published an Action Plan to modernize company law. One of the three main lines of action is aimed at enhancing transparency:

In order to encourage companies to enhance board diversity and give greater consideration to non-financial risks, the Commission will make a proposal in 2013 to strengthen disclosure requirements with regard to their board diversity policy and risk management through amendment of the accounting Directive. [Directive 78/660/EEC] ${ }^{10}$

To follow up on this line of action, in April 2013, the Commission published a proposal for a Directive to amend the EU Accounting Directives in order to enhance the transparency about the non-financial dimensions of the international business activities of large EU-based companies. ${ }^{11}$

\subsection{Reading Guideline}

Section 2 of this contribution concerns the question what information an MNC is obliged to disclose pursuant to the current Dutch law: (i) in the first section, we will examine what kind of information companies are required to include in their financial statements; (ii) in the second section, the Trade Register as a source of information will be discussed; and (iii) in the third section, we will address the disclosure requirements applicable to listed companies.

In Section 3, we will suggest possible legislative amendments that could enhance transparency concerning a Dutch MNC's business organization, the legal structure and its CSR profile.

As an add-on, the recent EU Commission's proposal for a Directive promoting reporting on non-financial corporate information ${ }^{12}$ will be discussed in Section 4, which will also contain the concluding remarks.

\subsection{Methodology, Limitations to the Research and Terminology}

The methodology comprised desk research, i.e. analyzing Dutch law. We limited the analysis to the following Dutch laws, which are the most pertinent ones regarding the theme of corporate transparency: Book 2 of the Dutch Civil Code (Burgerlijk Wetboek; i.e. the Dutch Company Act; hereafter: DCC); the Commercial Registers Act (Handelsregistermet); and the Dutch Act on

9. Van Wensen et al. 2011.

10. European Commission, 2012. Directive 2013/34/EU of 26 June 2013 replaces 78/660/EEG and 83/349/EEG.

11. European Commission 2013. A large company in this context refers to companies with more than 500 employees.

12. $I d$ 
Financial Supervision (Wet op het financieel toezicht [Wft]). The Dutch Corporate Governance Code is also included in the analysis. Tax legislation and competition legislation have not been taken into consideration. European law was taken into account where functional for answering the research question. ${ }^{13}$

In addition, the Utrecht research team conducted many brainstorm sessions amongst each other and also with AI NL and SOMO and organized discussions with academics from other universities at the aforementioned Ius Commune seminar.

The term 'Dutch $M N C$ ' used in this contribution refers to three situations: (i) a Dutch group of companies, whereby the parent company is incorporated under Dutch law, has a registered address in the Netherlands and is registered at a Chamber of Commerce in the Netherlands; (ii) a foreign MNC that has issued shares and/or bonds that are listed at the EURONEXT stock exchange in the Netherlands and hence is subjected to Dutch stock exchange laws and regulation; and (iii) an MNC that has not been established or listed in the Netherlands but has its economic basis in the Netherlands. ${ }^{14}$

The term 'legal structure' of an MNC as used in this contribution refers to the legal relationships between the legal entities and other business forms (e.g. partnerships) within the group; e.g. a 'Christmas tree' structure, comprising one parent company, various subholding companies, multiple subsidiaries (also called 'working companies' or 'operating companies') and partnerships in many countries (see Figure 1).

By 'business organization' or 'organizational chart', the authors refer to the manner in which the organization of a business has in fact been set up: does the MNC use a matrix model to divide tasks or attain to a hierarchical structure? Are the reporting lines organized per geographical region in which the activities take place or, for instance, per product line (see Figure 2)?

A reference in this contribution to an MNC's 'CSR profile' relates to the level of how CSR has been integrated in the business and governance of the MNC. For example, this concerns questions such as whether the MNC has a CSR mission statement; concrete ambitions and goals regarding CSR issues (e.g. $\mathrm{CO}_{2}$ reduction or compensation goals, water reduction goals, the reduction of workplace-related health, corruption, and human rights incidents, no-net loss biodiversity goals); adopted a company code of conduct or endorsed an international CSR code of conduct (e.g. the Global Compact, the OECD Guidelines, sector CSR codes of conduct); whether the MNC has introduced a programme to implement and enforce the CSR goals; whether the
MNC measures its positive and negative social and environmental impacts; whether the MNC engages in stakeholder dialogue; whether the MNC remedies negative impact; and whether the MNC publicly reports about the results of the implementation of its CSR programme.

\section{The Information Concerning MNCs Available Pursuant to Dutch Law}

This section will set out the Dutch statutory obligations of a company and MNC with regard to the disclosure of information concerning its worldwide legal structure, business organization, interests and activities, and CSR profile. Furthermore, the Dutch Corporate Governance Code will be discussed, which has a semi-legal status.

\subsection{Book 2 of the Dutch Civil Code}

The DCC contains the provisions applicable to the Dutch legal forms for business enterprises, especially concerning the private company with limited liability (besloten vennootschap $[B V]$ ) and the public company with limited liability (naamloze vennootschap $[N V]$ ).

Of relevance here are the provisions that pertain to the financial statements. These statements are intended to provide outsiders, i.e. shareholders and other interested parties, with an insight into the financial affairs of the company. Dutch private limited liability companies (BVs) and Dutch public limited liability companies (NVs) are required to publish (i) annual accounts, (ii) an annual report, and (iii) certain other information concerning the company and its business. ${ }^{15}$ The annual accounts consist of (a) a balance sheet, (b) a profit and loss account, and (c) the explanatory notes. ${ }^{16}$ They must also contain information about any financial interests of the company in other companies and should state whether the company is part of $a(n)$ (economic) group of companies. ${ }^{17}$ Besides the annual accounts, the board of directors has to draw up the annual report, the narrative part of the financial statements, also known as the 'directors' report'. ${ }^{18}$

Within five months after the end of the financial year, the board of directors has to present the annual accounts and the annual report to the shareholders for inspection and discussion at the general meeting of shareholders (GM). ${ }^{19}$ Extensions are sometimes possible. The objective of the presentation to the GM is that the GM for-
13. Id

14. The same limitation was applied in the report prepared for AI NL and SOMO by the Molengraaff Institute for Private Law, Utrecht University (2012; unpublished), with the title "MNCs en Transparantie. Een analyse van enige juridische en niet-juridische instrumenten voor het verkrijgen van meer transparantie ten aanzien van MNCs en (de schadelijke effecten van) hun grensoverschrijdende activiteiten" (Lennarts et al. 2012).
15. Art. 2:361 DCC, Art. 2:101 DCC for the Dutch public limited liability company (NV) and Art. 2:210 DCC for the Dutch private limited liability company (BV).

16. Art. 2:362 DCC.

17. Art. 2:379(1)(2) DCC.

18. Art. 2:360(1) DCC.

19. Art. 2:101 DCC for the Dutch public limited liability company (NV) and Art. 2:210 DCC for the Dutch private limited liability company (BV). 
mally decides to adopt the annual accounts. ${ }^{20}$ Within eight days after adoption, the annual accounts (together with the annual report and certain other information) must be made public by depositing them with the Trade Register, where the public can inspect them. ${ }^{21}$

In view of the research question, it is important to note that the annual report of large companies ${ }^{22}$ has to include an analysis of both financial and non-financial performance indicators, including environmental and employee matters, if this is necessary for a good understanding of the position, the development, and the results of the company or, in the case of consolidated accounts, of the legal person and group companies. ${ }^{23}$ The annual report shall also provide a description of the main risks and uncertainties that the company faces. Presently, this provision is the only statutory requirement that aims to create transparency concerning nonfinancial issues in the annual report, which also implies a forward-looking statement. However, the provision hardly gives any practical guidance to companies on how to prepare this part of the report, and it does not provide detailed instructions as to what such environmental and employee matters should comprise. ${ }^{24}$

Unfortunately, the information contained in an annual report and in the annual accounts does typically not provide an insight in the current affairs of a company/ MNC, but only sheds light on the situation in the previous year. Moreover, the law allows that the financial statements can be published many months after the financial year has ended.

Besides providing information about the financial results of the company at the end of the previous book year, the financial statements also provide information about financial participations of the company, i.e. the company must indicate in which legal entities it holds an interest exceeding $20 \%$ of the capital of that other legal entity. However, the financial statements do not contain detailed information about any contractual relationships of the company, such as regarding joint ventures in which the company or another group company participates. It is, therefore, impossible to get a full picture of the contractual network of the company including its franchise partners and supply chain partners.

20. Art. 2:101(3) DCC for the Dutch public limited liability company (NV) and Art. 2:210(3) DCC for the Dutch private limited liability company (BV).

21. Art. 2:394(1)(2) DCC.

22. Large companies are companies that do not qualify as medium-sized or small companies. A medium-sized company has to meet two of the following criteria: (i) net revenues do not exceed $€ 35$ million, (ii) total assets are not worth more than $€ 17.5$ million, and (iii) the company has not more than 250 employees (figures as per June 2013). Art. 2:397(1) (8) DCC.

23. Art. 2:391(1) DCC. Lambooy 2006

24. However, the Dutch Annual Report Guideline 400 issued by the Dutch Council for Annual Reporting provides more concrete guidance to companies and their accountants. Basically, it explains what should be included concerning the CSR aspects of conducting the worldwide business. Social and Economic Council of the Netherlands (SER), 2008.
A company which alone, or together with other group companies, is at the top of the group structure, ${ }^{25}$ i.e. the parent company, must additionally prepare consolidated annual accounts, which include the financial data concerning the group. ${ }^{26}$ This includes the financial results and other information concerning the parent company and of the following entities: (i) the subsidiary companies in the group; ${ }^{27}$ (ii) the other group companies; and (iii) any other legal entities in which the parent company can exert a controlling influence or impose central leadership. In such a situation, the Dutch subsidiary companies can be exempted from publishing a full set of annual accounts provided that the parent company has deposited a guarantee that covers certain debts of the subsidiary, a so-called '403-statement'. ${ }^{28}$

The information that must be provided through the financial statements, or the consolidated financial statements, traditionally served the purpose of informing the company's shareholders and creditors about the financial status quo of the company. This explains why other information that could possibly be interesting to the other stakeholders of the company (such as employees, consumers, communities, civil society) was lacking in the traditional reporting rules. The 2003 EU Modernisation Directive has changed this perspective and has introduced the obligation to also report on some nonfinancial subjects in the annual report indicated above). However, these requirements are worded in a very broad and unspecific manner. They do not oblige a company or a group of companies (such as an MNC) to systematically reveal information about its CSR profile, including information on the CSR strategy and mission, the CSR ambitions and concrete goals, any code(s) of conduct to which the company/MNC adheres, or internal protocols for employees, suppliers and business partners. There is thus neither any clear statutory obligation for a company/MNC to present a general and structured overview of the 'People, Planet and Profit' aspects of its business, nor any obligation to make a connection between that type of information and its financial outlook. 'Integrated reporting,' that is, integrating financial and non-financial information in all relevant

25. Art. 2:24b DCC: "A group is an economic unit in which legal persons and commercial partnerships are organizationally interconnected. Group companies are legal persons and commercial partnerships interconnected to each other in one group."

26. Art. 2:406(1)(2) DCC.

27. Art. 2:24a DCC states that: "a subsidiary of a legal person is: (a) a legal person in which another legal person or one or more of its subsidiaries, whether or not under a contract with other persons entitled to vote, is able to exercise, solely or jointly, more than one half of the voting rights at the General Meeting or (b) a legal person with regard to which another legal person or one or more of its subsidiaries, whether or not under a contract with other persons entitled to vote, is able to appoint or discharge, solely or jointly, more than one half of the members of the Board of Directors or the Supervisory Board, even if all persons entitled to vote would cast their vote."

28. See Art. 2:403(1)(f) DCC which states that the parent company has assumed in writing jointly and severally liability for debts arising from legal acts of the other legal person. This information has to be deposited at the Trade Register. 
reports and communications, including the annual report, is not (yet) required under Dutch law. ${ }^{29}$

In the Netherlands, so-called 'small' enterprises ${ }^{30}$ are exempted from preparing and publishing an annual report. Consequently, they do not have the duty to report on environmental and employee matters in their annual report. 'Medium-sized' enterprises do not have to report on these issues either as the law allows them not to report on the non-financial performance indicators in the annual report. ${ }^{31}$ The rationale of these exemptions for small and medium-sized companies is the reduction of the company's burden that comes with the obligations to report. These exemptions are in line with the EU Modernisation Directive. ${ }^{32}$

Currently, there are several developments that indicate or imply that an annual report has the function to also provide information relevant for other stakeholders than shareholders and creditors and that the information contained should also concern the business organization, the CSR profile and the results of the company's efforts to engage with such other stakeholders. ${ }^{33}$ This will be further explained in Section 4.

\subsection{Commercial Registers Act}

Under the Dutch Commercial Registers Act, legal entities must be registered with the Trade Register at the Chamber of Commerce. ${ }^{34}$ They must provide, amongst others, detailed information on their registered address and physical address, the names of the directors and supervisory directors, and proxy holders; they must deposit their deed of incorporation including (initial) articles of association, any amendments thereto, and their annual financial statements. ${ }^{35}$

The three objectives of the Commercial Registers Act are: (i) to promote legal certainty in commercial transactions; (ii) to provide general information about the composition of enterprises and legal entities in order to improve the economic interests of trade, industry, craft and services; and (iii) to register companies and legal entities to maintain data collections used by the government for policy-making. ${ }^{36}$

29. Lambooy \& Hordijk 2012.

30. Small companies are companies which meet two out of three criteria: (i) the net revenue is less than $€ 8.8$ million, (ii) the total assets are worth less than $€ 4.4$ million, and (iii) the company has less than 50 employees. See Art. 2:396(1)(7) DCC (figures as per June 2013).

31. Art. 2:397(1)(8)

32. Lambooy 2010. Nevertheless, if such a company's general meeting decides that the company should report and publish formation on environmental and personnel matters, it can decide that these exemptions do not apply.

33. Since the last decade, the range of people to which the financial statements are addressed have been broadened. Today, a company often explicitly mentions other stakeholders in its annual report and it explains and justifies its activities to them. This new perspective can also be read in the preamble of the European Modernisation Directive 2003/51/EC (which is the basis for the Dutch legal provisions) and the Dutch Corporate Governance Code (see below). The European Modernisation Directive amended the European Accounting Directives. Art. 2:391 DCC is in line with the European provisions. See: Lambooy 2010; Lambooy 2006.

34. Art. 5 Commercial Registers Act.

35. Arts. 9-14 Commercial Registers Act.

36. Art. 2 Commercial Registers Act.
The purpose of the registration obligation is to provide third parties with the possibility to obtain information about the company, for instance, if such third party wants to contract with the company. The traditional rationale behind this obligation was not concerned with informing other stakeholders about the company. Information which is deposited with the Trade Register is publicly available for inspection via online facilities or in hard copies at the Chambers of Commerce.

A Dutch private limited liability company (BV) and a Dutch public limited liability company (NV) must be registered with the Trade Register at the Chamber of Commerce located in the district where the company has its office address. ${ }^{37} \mathrm{~A}$ company with a business outside the Netherlands must be registered with the Trade Register in the district where its corporate seat is located. ${ }^{38}$ According to the Commercial Registers Act, not all companies have to be registered. The companies that have to be registered can be divided into four main groups: (i) an enterprise that is established in the Netherlands and belongs to a Dutch individual or legal entity; (ii) an enterprise that belongs to a European company that according to its articles of association has its registered office in the Netherlands; (iii) an enterprise that belongs to a foreign legal person of which the headquarters or branch office is located in the Netherlands; and (iv) an enterprise that is established in the Netherlands and that belongs to another than the entities mentioned before. ${ }^{39}$

If the company just has one shareholder who owns a $100 \%$ of the shares, information about the shareholder must be registered with the Trade Register. ${ }^{40}$ If the company has multiple shareholders, the Trade Register does not contain any information about their identity. ${ }^{41}$ The company, however, will have to maintain a shareholders' register, but this is not publicly accessible (only accessible for shareholders). Hence, it will be difficult for third parties to obtain any information about the company's shareholders when the company has multiple shareholders. ${ }^{42}$ Different rules apply to listed companies (see Sections 2.3 and 2.4).

As regards a group of companies, the Dutch Trade Register only provides information on the group relationships of a registered company to the extent that these group relationships concern Dutch group companies. When a foreign, non-Dutch, legal entity becomes part of the group, then information about this entity and the relationships it may have with the Dutch group members cannot be obtained through the Dutch Trade Register. ${ }^{43}$ Neither does the Dutch Trade Register provide any information on agreements such as joint venture

37. Art. 18(6) Commercial Registers Act.

38. Art. 2:66 DCC for the Dutch public limited liability company and Art. 2:177 DCC for the Dutch private limited liability company (BV).

39. Art. 5 Commercial Registers Act.

40. Art. 22 (1)(e) Commercial Registers Decree 2008.

41. Please see the website of the Dutch Chamber of Commerce.

42. Art. 2:85 (1)(4) DCC for the Dutch public limited liability company (NV) and Art. 2:194(1)(4) DCC for the Dutch private limited liability company (BV).

43. Arts. 5 and 6 Commercial Registers Act. 


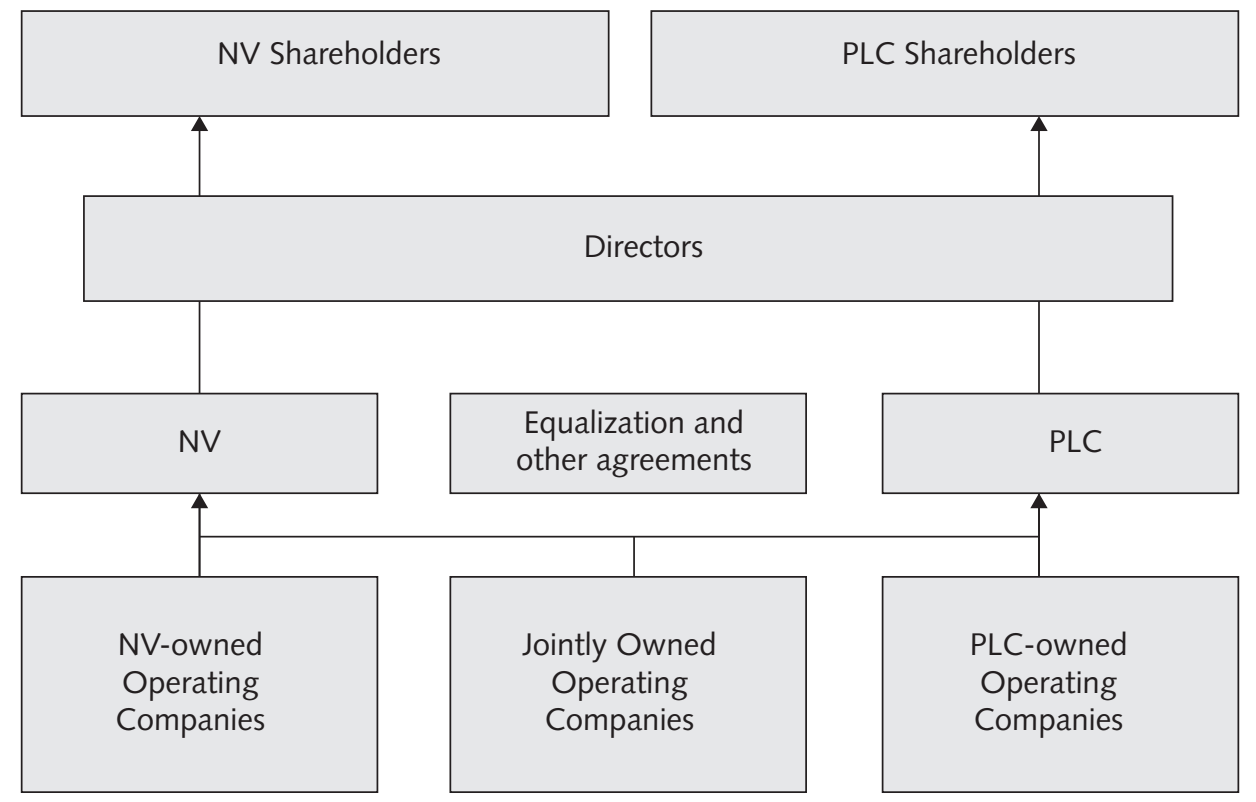

Source: Please see the website of Unilever.

agreements, shareholder agreements, and franchise agreements. The Dutch Trade Register thus fails to give a clear-cut view of MNCs, their worldwide legal structure (i.e. the 'Christmas tree') and the way in which their business activities have been organized (i.e. the business organization or organizational chart). ${ }^{44}$

Companies often include information about their legal structure and business organization in their annual report (part of the Trade Register information) or on their website, but this usually concerns a simplified version of reality. See, for illustration purposes, the top legal structure of Unilever and the business chart of Philips. From these figures, it is apparent that the publicly available information is a simplification of the full legal structure and organizational chart of such an MNC.

Figure 1 shows the legal top structure of the MNC Unilever as it has been made publicly available at one of Unilever's websites. ${ }^{45}$ According to the available information in the Trade Register, Unilever Netherlands Holding B.V. is shareholder of Unilever B.V. The shareholder of Unilever Nederland Holdings B.V. is Unilever N.V. Unfortunately, the Trade Register does not contain any information about the Jointly Owned Operating Companies, Equalization and other agreements, and about the parent company Unilever PLC.

Figure 2 shows the organizational chart of the MNC Philips as it has been made publicly available at one of Philips' websites. This information does not align with the information that is available in the Trade Register about Philips. For instance, Philips Healthcare is not registered as a legal entity in the Dutch Trade Register. We assume that it is the name of a division or business line.

44. Lambooy et al. 2013 (forthcoming). See also, Mintzberg 1979.

45. Unilever 2010
Traditionally, a Dutch private limited liability company (BV) and a Dutch public limited liability company (NV) were employed for managing one enterprise. The information that can be obtained from a Dutch Trade Register reflects this traditional situation. An interested party can learn about the date of incorporation of the company, the company's objectives, and about the founders of the company. If there is one shareholder, information about this shareholder can also be found in the Trade Register. In addition, the Trade Register contains information about the members of the board of directors and the supervisory board and about who holds a power of attorney to bind the company in contractual arrangements. As noted above, information about shareholder agreements and joint venture agreements are not available at the Chamber of Commerce.

So far so good, however, when a Dutch private limited liability company (BV) or a Dutch public limited liability company (NV) is part of a group of companies, the information becomes less clear. The Dutch Trade Register does provide information about the identity of group partners ('concern relaties'). However, in respect of every group partner, a new query has to be initiated if the stakeholder wishes to acquire information about such group partner's directors, articles of association, annual accounts, et cetera. As long as this group partner concerns another Dutch company, the information can still be obtained from the Trade Register. However, for every query, a certain financial compensation has to be paid. In respect of group partners that are organized as a foreign legal entity or in any other form, the stakeholder can only try to obtain the required information via the pertinent foreign trade register. Considering the fact that most MNCs comprise hundreds of legal entities and contractual ventures dispersed around the world, the traditional way in which the Dutch Trade Register 
Philips Healthcare

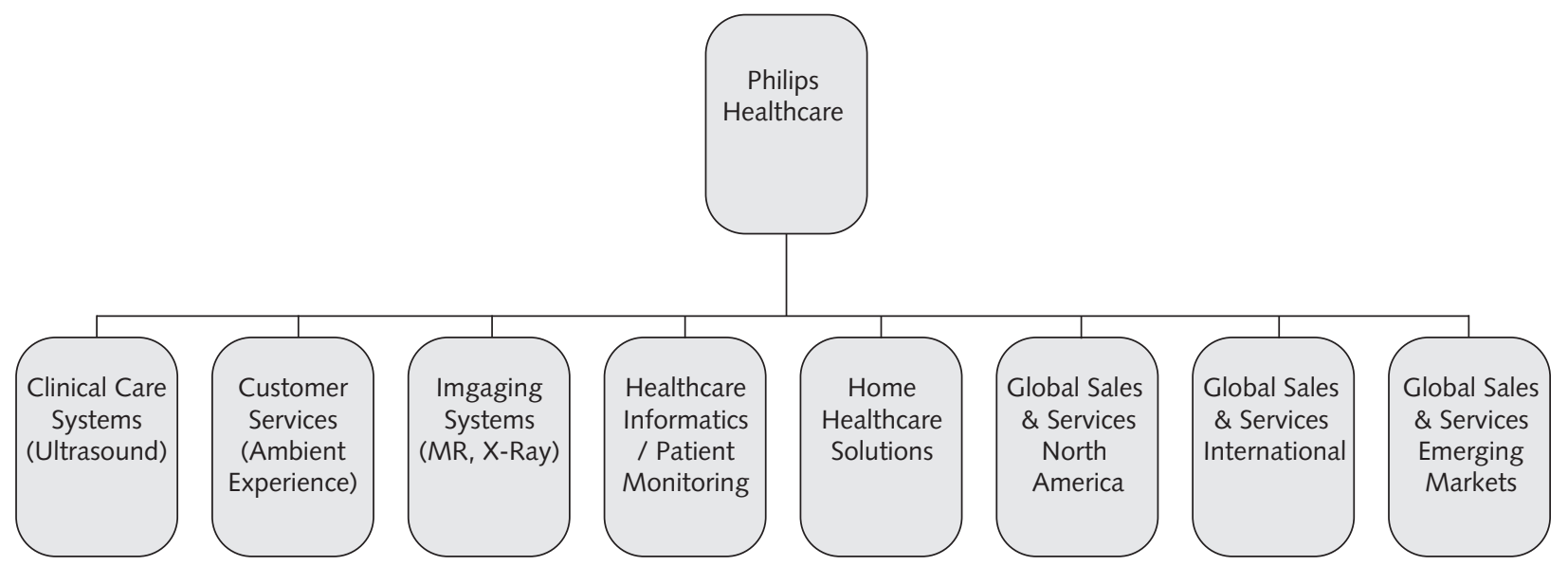

Source: Please see the website of Philips.

has been organized no longer meets the three objectives of the Dutch Commercial Registers Act, which were stated at the beginning of this section (i.e. [i] to promote legal certainty in commercial transactions; [ii] to provide general information about the composition of enterprises and legal entities; and [iii] to register companies and legal entities to maintain data collections used by the government for policy-making). In particular, concerning an MNC, the second objective will not often be realized.

\subsection{The Act on Financial Supervision}

To listed companies, various additional statutory and semi-legal obligations apply. They all aim to provide more information to the stock market about a listed company's business, its results and the risks that might affect the results in the near and longer future. In the Netherlands, the Act on Financial Supervision applies to listed companies and contains many provisions that lead to more transparency about the corporate affairs of a listed company. Very important for shareholders are the Act's provisions on the mandatory and timely corporate disclosures of the periodic financial results and of any events that could affect the financial results of the company (or group).

Other important sources of information concerning a listed company's business are the prospectus and the public offer memorandum. A prospectus is published by a company that offers (new) shares or other securities on the stock market. It is drafted by that company and its banks. A public offer memorandum plays a role in a public bid for shares in a listed company. It is published by the bidder. The prospectus and the public offer memorandum are regulated by the Act and serve the purpose of informing potential respectively current shareholders about the new listing and the public bid. ${ }^{46}$

\subsubsection{Prospectus}

Concerning a public offering of securities or the admission of securities to a stock exchange situated or operating in the Netherlands, the Act stipulates that a prospectus is made generally available in respect of the offer or admission that has been approved by the Authority for the Financial Markets or by a supervisory authority of another Member State. ${ }^{47}$ The prospectus contains information relevant for prospective investors who might be interested in buying new shares in case of a public offer or an emission of shares or other securities. Basically, it can be seen as a sales brochure containing information about the newly to-be-listed securities, the company (or group), its directors, incorporators and/or shareholders, type of business and financial results and risks that might impact future results.

Usually, the shares that will be listed are shares (to be) issued by the parent company of a group, that is, shares that, in value and potential profitability, reflect the business activities of the whole group. The information provided in a prospectus is supposed to explain the legal structure of the group and the organizational chart, the strategy and management of the group, the business activities, how the future earnings will be realized, and the manner in which potential risks are addressed. The information in a prospectus pertains the worldwide business activities of the group as that is relevant for understanding how the value is (will be) created and how the future earnings will be realized. Thus, a prospectus cannot suffice with only presenting the affairs concerning the parent company. Investors are interested in the group's potential of share value creation and dividend perspectives; hence, the prospectus has to substantiate any statements about the financial expectations for the future. In this way, it differs from the financial (consolidated) statements, which primarily look backwards

47. This is regulated in Art. 5:2 et seq. of the Dutch Financial Supervision Act. 
and serve the purpose to account for the performance over the last book year to existing shareholders.

\subsubsection{Public Offer Memorandum}

The Act states that a party who intends to make a public bid for listed securities must draw up and publish a public offer memorandum in order to provide information about the bid, the price offered for the securities, and about the bidder itself, to the current holders of the securities. ${ }^{48}$ The object is to provide the latter with sufficient information so that they can make an informed decision whether or not to offer their securities for the proposed price to the bidder. To make an informed decision is only possible when the holder of the securities receives sufficient information that can substantiate the bid price. When the bidder offers to the security holders of the target company an exchange for securities in its own group, the information has to shed a light on the financial prospects of the bidder group. Often, a public offer memorandum contains the same type of information that is presented in a prospectus.

Although the information in the prospectus and the public offer memorandum focuses on (potential) shareholders, such information can also be useful for other stakeholders as it reveals often more about the worldwide business activities of a listed company than the (consolidated) financial statements do. However, the prospectus and the public offer memorandum, like the financial statements, only portray a company's (or group's) situation at a certain moment, i.e. the moment on which the announcement has been made that the new shares will be issued or listed, respectively, the moment on which the public offer has been announced. Hence, these documents do neither provide a systematic insight into the affairs of the company and its group nor into its business organization and CSR profile, whereas such information can be material for the value of the company/MNC and for the estimation of the prospects. ${ }^{49}$

\subsection{Corporate Governance Code (Code Frijns)}

The 2008 Dutch Corporate Governance Code ${ }^{50}$ applies to listed companies. The Code does not qualify as law. It concerns a private regulatory regime. ${ }^{51}$ However, like in other European jurisdictions, Dutch corporate law obliges listed companies to indicate in their annual report if they comply with this Code and if not, they have to clarify why and with which provisions they do not comply. ${ }^{52}$ For our analysis, the Code is relevant because it prescribes to listed companies to share certain information about the company's CSR profile.

The Code contains principles and best practice provisions that regulate the relationships between the board of directors, the supervisory board and the shareholders of listed companies.
In relation to CSR, the Code's principles stipulate that the board of directors deals with CSR issues and policies that are relevant to the enterprise, ${ }^{53}$ submit these for approval to the supervisory board, ${ }^{54}$ and inform the shareholders about this. ${ }^{55}$ The Code refers also to the interests of stakeholders and makes it explicit that stakeholders comprise of various groups, including shareholders, employees, communities and others. ${ }^{56}$

The Code does not clarify where a stakeholder can find the CSR strategy and policies. For a stakeholder, it will also not be easy to find information about any discussion between the board of directors and the supervisory board relating to CSR topics. However, as the company has to provide information in its annual report about its compliance, or failures to comply, with the Code, it should also explain whether it complies with the provisions concerning its CSR profile. If the company does not provide this information, it has to explain why not.

\subsection{Conclusion}

The current Dutch laws and regulations pertaining to the information that a company has to share with its stakeholders were traditionally drafted with the objective to provide financial information to the creditors and shareholders. The rationale behind this was that creditors and investors need financial and practical information about the company with which they do business and in which they invest. This explains why the focus was on financial information rather than on non-financial information such as the CSR profile of a company (although, according to current insights, this information can be very relevant, also from a financial point of view). ${ }^{57}$

Globalization stimulated international trade and the expanding size of MNCs. Today, the Dutch Trade Register fails in providing adequate information about the foreign parts of a group. The annual reporting laws fail to require companies to provide an insight in the group's legal structure, the business organization and the CSR profile of an MNC. And even the Act on Financial Supervision fails to include disclosure requirements regarding the CSR profile of a listed company.

The authors conclude that there is a gap in Dutch law concerning the information provision to stakeholders, i.e. shareholders as well as other parties interested or affected by an MNC's affairs. The authors will identify options for improvement in Section 3.

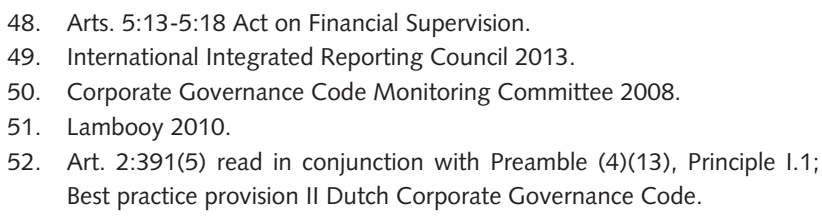

53. Principle II.1 Dutch Corporate Governance Code.

54. Best practice provision II.1.2 Dutch Corporate Governance Code.

55. Principle III.1; Best practice provision III.1.6.g; Best practice provision II. 1.2 Dutch Corporate Governance Code.

56. Preamble No. 7 Dutch Corporate Governance Code.

57. Please see the website of Principles of Responsible Investment. 


\section{Identification of Options to Enhance Transparency through Dutch Corporate and Financial Law}

The analysis of Dutch law on transparency requirements for MNCs was conducted with the objective to identify options to amend the laws in order to improve transparency. This section will suggest proposals to extend the transparency requirements for large companies as currently contained in Book 2 of the Dutch Civil Code, to improve the accessibility of information through the Commercial Registers Act, and finally to use the disclosures pursuant to the Act on Financial Supervision in a more productive way to also serve other stakeholders besides shareholders.

\subsection{Options to Extend the Annual Reporting Requirements}

The first proposal is to extend Book 2 of the Dutch Civil Code with more provisions in the title on corporate reporting, for instance, by requiring companies to also include information in their annual reports regarding the organization of their business activities. One could imagine that the law requires companies to map their worldwide business organization and the legal Christmas tree and to indicate to what extent their business organization aligns or diverges with the legal structure of their group. Moreover, companies could be required to include information on their CSR profile in their annual reports. Such a requirement could go hand in hand with requiring the companies to engage external verification of such non-financial information.

This proposal firstly relates to listed companies. The rationale would be that they are public companies that do business with funds obtained from the public, mostly from institutional investors. CSR presumes that listed companies assume the responsibility to explain how they are organized and in which way and where they operate (with power comes responsibility). Arguably, such transparency obligations could also be made applicable to large non-listed companies. The rationale for this could be that large MNCs use many resources, for example, energy, water, raw materials and other ecosystem services. They often employ many people in their operations.

A second option relates to the appliance of integrated reporting. Currently, the international trend is to consider the introduction of integrated reporting. Multiple MNCs, such as Unilever and the Coca-Cola Company, are experimenting with integrated reporting to improve their transparency. ${ }^{58}$ An integrated report connects any material, financial and non-financial information in a meaningful way for investors and other stakeholders. This is a new development in the field of annual report- ing. Various countries are in the process of developing new legislation in the field of integrated reporting. ${ }^{99}$ South Africa was the first country, where listed companies were obliged to publish an integrated report. ${ }^{60} \mathrm{Sim}-$ ilar legislation could be adopted in Book 2 of the DCC or in the Dutch Corporate Governance Code. ${ }^{61}$

A third proposal for improving corporate transparency is to oblige companies to publish their annual report on their website. This will enhance the accessibility for stakeholders. Although companies tend to do so, there is yet no legal obligation for companies to make their reports publicly available on their websites. For listed companies, the Act on Financial Supervision already requires them to publish all the regulated information on their websites, including their annual reports. Since everybody mainly obtains corporate information using the Web today, it makes sense to require the same for other companies. This would make it easy for interested parties to access annual reports (otherwise they have to obtain the information from the Trade Register and pay for the Trade Register's services).

\subsection{Options to Amend the Commercial Registers Act}

Options to amend the Commercial Registers Act include the introduction of provisions that require of companies to provide information on the legal structure of their group of companies and information on the business organization of the company (or as the case may be, the group). Companies could be required to deposit this type of information with the Trade Register and update it whenever changes occur. Or they could create an electronic link from the Trade Register to their webpage where they can keep track of the latest situation. Of particular relevance is that companies create transparency on the question which legal person(s) is controlling the group and/or the company.

Another way of approaching the transparency issue is to make information filed with the Trade Register available online for stakeholders without any financial charge. As was explained before, a stakeholder presently has to pay for obtaining Trade Register information and for every group company he has to file a new query. This rule also stems from a time when Trade Register employees had to make hard copies of original documents in order to send these by regular mail to the interested party. Today, the information can be made available through electronic systems. Hence, an argument could be made that requests for corporate information, i.e. without asking for official copies, should not be charged.

Finally, the option was identified that the Dutch Trade Register could set up partnerships with foreign trade registers aimed at linking the systems in order to make information about group companies that are registered elsewhere accessible in an easy way for stakeholders in

59. See the website of the Global Reporting Initiative for the latest developments: <www.globalreporting.org/information/news-and-press-center/ Pages/default.aspx>. See also <www.iirc.org $>$

60. See King Committee 2009.

61. Lambooy et al. 2013. 
the Netherlands and, currently, possibly also accessible for stakeholders situated in other countries. An alternative method would be that Dutch parent companies deposit a shadow file with information on their foreign subsidiaries at the Dutch Trade Register or that they provide a free link at their website to the information about their foreign subsidiaries, which is kept at foreign trade registers.

\subsection{Options to Expand the Disclosure}

Requirements concerning Listed Companies (Act on Financial Supervision and EU Law)

The Prospectus Directive and the Act on the Financial Supervision give an insight in what kind of information is important for shareholders and stakeholders. Both pieces of legislation require that securities issuers (i.e. the listed companies) provide information about the organizational structure and the business activities of their international group. The authors note that it is an option to expand this obligation by explicitly requiring detailed information on the CSR profile of the listed company (and its group).

A second option to enhance corporate transparency concerning MNCs is the following. As a prospectus must include a summary of the essential characteristics and the risks of the company and its securities, it would be useful if such information would be updated on an annual basis and filed with the Authority for the Financial Markets (Autoriteit Financiële Markten) as well as on the company's website (category: investors relationships/investor communication). Similar requirements apply in the United States, where issuers must file a lot of relevant information with the Securities and Exchange Commission on an annual basis (see also the contribution of Van der Heijden in this issue).

This proposal would also be relevant for the European Securities Directives (the Transparency Directive ${ }^{62}$ and the Prospectus Directive $\left.{ }^{63}\right)$.

\subsection{Information Platforms}

Complementary to the aforementioned options, there are various options to create an information platform where all stakeholders can obtain the information that they need.

One practical option would be that a company or an MNC uses its main website as an 'information hub' (preferably the website of the parent company). This website should certainly contain a Christmas tree showing the legal structure of the group as well as a chart of the worldwide business organization. It would be useful if the company/MNC clarifies whether the business organization aligns with the legal structure and, if this is not the case, to what extent the two structures diverge and why. Moreover, the CSR profile can be presented and any annual or integrated reports can be made available. The same is possible for any prospectus or public offer memorandum that was ever published by the parent company or any of the group companies.

62. European Parliament and the European Council 2004.

63. European Parliament the European Council 2010.
A second option is to employ the platform of the Trade Register to share corporate information.

Thirdly, the information relating to listed companies and large groups of companies could also be made accessible via the database of the Authority for the Financial Markets. This information is meant to inform investors of listed companies, but is also relevant for other stakeholders.

Furthermore, regarding all three options, all information obviously has to be correct and therefore independent experts, e.g. accountants, have to verify whether the information is correct. These experts could, for example, utilize reporting frameworks, such as the International Integrated Reporting Framework, or sustainability reporting guidelines, such as the Global Reporting Initiative G4, to assess the quality of the disclosed information by a company in a company's annual or integrated report. Verification would apply to all categories of information.

Moreover, it is important that all information is always up-to-date. Hence, it is important to require that companies update any information that they disclose, as soon as such information becomes outdated.

\subsection{Proposal for an EU Directive}

The Commission recently proposed a Directive ${ }^{64}$ concerning the disclosure of non-financial and diversity information by certain large companies ${ }^{65}$ and groups (hereafter: 'the Proposal'). The objectives of the Proposal are: (i) to increase the transparency of certain companies and to increase the relevance, consistency and comparability of the non-financial information currently disclosed; (ii) to increase diversity in the boards of companies through enhanced transparency in order to facilitate an effective oversight of the management and governance of the company; and (iii) to increase the company's accountability and performance and the efficiency of the European single market. ${ }^{66}$ The Proposal states:

The proposal shall amend provisions of the Accounting Directives. ${ }^{67}$ The Accounting Directives regulate the information provided in the financial statements of all limited liability companies which are incorporated under the law of a Member State or European Economic Area (EEA). The amendments proposed to these provisions will also cover companies listed on EU regulated markets even if they are registered in a third country. ${ }^{68}$

64. European Commission 2013

65. A large company as referred to in the Proposal is a company which has more than 500 employees and which balance sheet total exceeds $€ 20$ million or which has a net turnover of $€ 40$ million or more. This threshold is higher than the one which currently applies pursuant to the Accounting Directives ( $>250$ employees and other financial thresholds).

66. European Commission 2013, p. 3.

67. Fourth Council Directive 78/660 EEC of 25 July 1978 on the annual accounts of certain types of companies and the Seventh Council Directive 83/349/EEC of 13 June 1983 on consolidated accounts. See note 10 re the new Accounting Directive.

68. European Commission 2013 p. 6 
Let us compare this Proposal to the current provisions of the Accounting Directives, which have been implemented in Dutch law under the title on annual reporting in Book 2 DCC. The current provisions oblige large companies to disclose non-financial information, including information relating to environmental and employee matters. As mentioned in Section 2.1, non-financial information only has to be disclosed if this is necessary for a good understanding of the position, the development, and the results of the company or, in the case of consolidated accounts, of the legal person and group companies. ${ }^{69}$ Disclosure of non-financial information is thus limited to these cases. The Proposal goes a step further by removing these limitations and requiring large companies to include a 'non-financial statement' in their annual report. Hence, this will apply to all large companies at any time.

Furthermore, the Proposal also explains in a more detailed way than the current legislation what type of information must be shared in the non-financial statement. That is, containing information relating to at least environmental, social and employee-related matters, respect for human rights, anti-corruption and bribery aspects. By adding these categories, the Proposal explains more clearly than Book 2 DCC (and the underlying EU Modernisation Directive) which issues fall under the category of non-financial information. When a company does not pursue policies in relation to one or more of the previous matters, it shall provide an explanation in its annual report for not doing so. The analysis shall include both financial and non-financial key performance indicators relevant to the particular business if necessary for an understanding of the company's development, performance or position. ${ }^{70}$

The Proposal also adds a new paragraph ${ }^{71}$ that will oblige large listed companies to provide information on their diversity policy, including aspects concerning age, gender, geographical diversity and educational and professional background. The information will be included in the corporate governance statement and will have to contain the objectives of such a policy, its implementation and the results obtained.

If the Proposal would be adopted, the Dutch regulator would have to amend the DCC accordingly. It usually does so in a very literal manner when it regards corporate law and accounting rules. ${ }^{72}$ The Proposal does not provide for regulatory options; hence, there will be no possibility for the Dutch regulator to make choices in the implementation of the directive in Dutch law.

Concluding, although the Proposal contains additional reporting requirements for MNCs relating to CSR issues, the wording is again very broad, like in the Modernisation Directive. To enhance transparency and accessibility for stakeholders, it is necessary to create clear rules with detailed user guidelines, so that publicly

69. Art. 2:391 (1) DCC.

70. European Commission 2013 pp. 6 and 11-12.

71. European Commission 2013 p. 12.

72. Lambooy 2010 available corporate information will be accessible, comparable and reliable. The options that the authors identified in this contribution are clearer, more creative and more practical than the Proposal's requirements.

\section{Conclusion}

In this article, we have analyzed what type of corporate and business information a company or an MNC must make public pursuant to Book 2 of the Dutch Civil Code, the Dutch Commercial Registers Act and the Dutch Act on Financial Supervision. We demonstrated that the existing regulatory framework in the Netherlands does not succeed in providing any transparency concerning the opacity that currently exists relating to an MNC's business organization, legal structure and power structure.

The existing lack of transparency constitutes a problem for stakeholders who want to understand how a group of companies is organized and how it conducts its activities. Stakeholders include both parties who have a financial interest in an MNC and parties who are affected by an MNC's business activities. Also policymakers have difficulties in developing legislation and policies if they do not understand the power and strategies of MNCs. We also noted that there is a trend amongst investors and other stakeholders towards demanding a higher level of corporate transparency. This is a global trend and is not limited to the Netherlands. Various MNCs have also shown an interest in participating in pilot projects aimed at increasing corporate transparency. The development of integrated reporting provides only one example whereby an increasing number of large MNCs, such as the Coca-Cola Company and Unilever, are experimenting in preparing an integrated report.

However, in order to really change the status quo, new legislation is indispensable, because only a clear regulatory framework will cause MNCs to produce disclosures that are (i) comparable, (ii) truthful due to external verification, and (iii) up-to-date.

We searched for options to improve the Dutch legal framework with the objective to make corporate information better accessible for stakeholders. Various options were discussed. These included options of a legal nature, e.g. proposals to expand the type of information that companies must disclose in their annual report, through the Trade Register, and in their prospectus and public offer memoranda; the timing thereof and the verification of the correctness of the disclosed information. We also presented more practical options, e.g. to connect the information that is available in Dutch and foreign trade registers in regard of groups of companies. We came up with a number of proposals to deal with the challenges identified. Each of them can contribute to shed more light on an MNC's business organization, legal structure and power structure. Most of our proposals can also be applied to the European legal norms and in other legal systems. 


\section{Bibliography}

Academic articles and books

R.G. Eccles \& G. Serafeim, "Market Interest in Nonfinancial Information", 23 Fournal of Applied Corporate Finance 4, 2011, p. 113.

L. Enneking et al., "Privaatrechtelijke handhaving in reactie op mensenrechtenschendingen door internationaal opererende ondernemingen", 36 Nederlands Tijdschrift voor de Mensenrechten 5, 2011, pp. 541-560.

T.E. Lambooy, "Aspecten maatschappelijk verantwoord ondernemen in jaarverslag: Transparantie over MVO op Europees niveau", 31 Ondernemingsrecht, 2006, p. 1.

T.E. Lambooy, Corporate Social Responsibility: Legal and SemiLegal Framemorks Supporting CSR - Developments 2000-2010, Deventer, Kluwer, 2010.

T.E. Lambooy et al., "Corporate Social Responsibility and Transparency: How Could We Amend Dutch law to improve transparency with regard to Dutch multinational companies? Conference Report CSR Workshop, 17th Annual Ius Commune Conference, 29 November 2012, Amsterdam”, International and Comparative Corporate Law Fournal, forthcoming 2013.

T.E. Lambooy \& R.M. Hordijk, "De tijd is rijp voor integrated reporting”, 2 Tijdschrift voor faarrekeningrecht 3, 2012, pp. 54-63.

T.E. Lambooy et al., "Integrated Reporting - To measure is to know. Conference report 'Integrated Reporting - Measuring = Knowing,' 30 May 2012, Rotterdam”, 5 Tijdschrift voor Faarrekeningenrecht, 2013, pp.162-168.

H. Mintzberg, The Structuring of Organizations: A Synthesis of the Research, Prentice-Hall, 1979.

Case law

Rechtbank 's-Gravenhage 30 January 2013, LJN BY9845, available at (in Dutch): <http://zoeken.rechtspraak.nl/result page. aspx? 'snelzoeken $=$ true $\&$ searchtype $=\operatorname{ljn} \&$ ljn $=$ BY $9845 \&$ vrije_tekst $=$ shell $>$ (last accessed 26 July 2013).

Rechtbank 's-Gravenhage 30 January 2013, LJN BY9850, available at (in Dutch): <http://zoeken.rechtspraak.nl/result page. aspx? snelzoeken $=$ true\&searchtype $=$ ljn $\&$ ljn $=$ BY9850\& vrije_tekst $=$ shell $>$ (last accessed 26 July 2013 ).

Rechtbank 's-Gravenhage 30 January 2013, LJN BY9854, available at (in Dutch): <http://zoeken.rechtspraak.nl/result page. aspx? 'snelzoeken $=$ true\&searchtype $=$ ljn\&ljn $=$ BY $9854 \&$ vrije_tekst $=$ shell $>$ (last accessed 26 July 2013).

\section{Legislation and policy documents}

Corporate Governance Code Monitoring Committee, "Dutch corporate governance code. Principles of good corporate governance and best practice provisions", 2008, available at: <www.mccg.nl/download/?id=606> (last accessed 26 July 2013).

European Commission, "Action Plan: European company law and corporate governance - a modern legal framework for more engaged shareholders and sustainable companies", 2012, p. 6, available at: <http://ec.europa.eu/internal_market/ company/docs/modern/121212_company-law-corporategov ernance-action-plan_en.pdf $>$ (last accessed 17 June 2013).

European Commission, "Proposal for a Directive of the European Parliament and of the Council amending Council Directives 78/660/EEC and 83/349/EEC as regards disclosure of nonfinancial and diversity information by certain large companies and groups" $\operatorname{COM}(2013)$ 207, 2013.

European Parliament and the European Council, "Directive 2004/109/EC of the European Parliament and of the Council of 15 December 2004 on the harmonisation of transparency requirements in relation to information about issuers whose securities are admitted to trading on a regulated market and amending Directive 2001/34/EC", 2004.

European Parliament and the European Council, "Directive 2010/73/EU of the European Parliament and of the Council of 24 November 2010 amending Directives 2003/71/EC on the prospectus to be published when securities are offered to the public or admitted to trading and 2004/109/EC on the harmonisation of transparency requirements in relation to information about issuers whose securities are admitted to trading on a regulated market", 2010.

European Parliament and the European Council, "Directive 2013/34/EU of the European Parliament and of the Council of 26 June 2013 on the annual financial statements, consolidated financial statements and related reports of certain types of undertakings, amending Directive 2006/43/EC of the European Parliament and of the Council and repealing Council Directives 78/660/EEC and 83/349/EEC”, 2013.

King Committee, "King III Code on Corporate Governance", 2009, available at: <http://www.massmart.co.za/pdf/ king_code_of_governance_for_sa_2009.pdf> (last accessed 26 July 2013).

Social and Economic Council of the Netherlands (SER), "Statement on International Corporate Social Responsibility 2008", 2008, pp. 67-76, available at: <www.ser.nl/en/publications/ publications/2008/ /media/Files/Internet/Talen/Engels/ 2008/b27428/b27428_en_5.ashx> (last accessed 26 July 2013).

\section{Reports}

International Integrated Reporting Council, "Consultation draft of the international <IR $>$ Framework", 2013, p. 21, available at: <www.theiirc.org/consultationdraft2013> (last accessed 30 July 2013).

M.L. Lennarts et al., "MNCs en Transparantie. Een analyse van enige juridische en niet-juridische instrumenten voor het verkrijgen van meer transparantie ten aanzien van MNCs en (de schadelijke effecten van) hun grensoverschrijdende activiteiten”, unpublished, 2012.

Unilever, "The Governance of Unilever," 2010, available at: <http://unilever.com/images/ir20100428TheGovernanceof Unilever200510tcm13216301.pdf> (last accessed 26 July 2013).

K. van Wensen et al., "The state of play in sustainability reporting in the European Union”, European Union, 2011, pp. 30-31.

\section{Websites}

Amnesty International, "Netherlands. Human rights in the kingdom of the Netherlands", folder without publishing date, available at: <www.amnesty.org/en/region/netherlands> (last accessed 26 July 2013).

The Dutch Chamber of Commerce, "Help Handelsregister Online", website information, available at: $<$ https://server. db.kvk.nl/wwwsrvu/html/hl_concernhelp.html> (last accessed: 27 July 2013).

Friends of the Earth Netherlands, "Information for Press", article without publishing date, available at: <www.milieudefen sie.nl/english/shell/oil-leaks/courtcase/press> (last accessed 26 July 2013).

Friends of the Earth Netherlands, "Uitspraak Shell-zaak geweldig voor Ikot Ada Udo. Hoop voor anderen", article without publishing date, available at: <www.milieudefensie.nl/olie winning/nieuws/uitspraak-shell-zaak-geweldig-voor-ikotadaudo.-daarnaast-precedent> (last accessed 26 July 2013).

Friends of the Earth Netherlands, "Nigerians and Milieudefensie appeal in Shell case", 1 May 2013, available at: <www.milieu defensie.nl/english/shell/news/nigerians-and-milieudefen sie-appeal-in-shell-case> (last accessed 13 October 2013). 
Global Reporting Initiative, "News and Press Center", website information, available at: <www.globalreporting.org/infor mation/news-and-press-center/Pages/default.aspx $>$ (last accessed 26 July 2013).

International Integrated Reporting Council, website information, available at: <www.iirc.org > (last accessed 30 July 2013).

International Integrated Reporting Council, "Pilot Programme Business Network", August 2013, available at: <www.theiirc.org/wp-content/uploads/2013/09/IIRC-

Pilot-Programme-Business-Network-backgrounderAugust-2013.pdf $>$ (last accessed 15 October 2013).

Principles for Responsible Investment, "Home", website information, available at: <www.unpri.org/> (last accessed 26 July 2013).

Principles for Responsible Investment, "Introducing responsible investment," website information, available at: $<$ www.unpri.org/introducing-responsible-investment/> (last accessed 30 July 2013).

Philips, "Philips Healthcare", website information, available at: <www.philips.nl/shared/assets/nl/LargeParagraphImage/ Philips_Healthcare_Organization_chart.png $>$ (last accessed 26 July 2013).

SOMO, "Welcome", website information, available at: <http:// somo.nl/?set_language $=\mathrm{en}>($ last accessed 26 July 2013). 